\title{
DOES THE CRIME PAY OFF - (UN)EFFICIENCY OF CONFISCATION IN CROATIA - NEW PROPOSALS FOR ITS 60TH BIRTHDAY
}

\author{
Sunčana Roksandić Vidička, PhD, Assistant Professor \\ University of Zagreb, Faculty of Law \\ Trg Republike Hrvatske 14, Zagreb, Croatia \\ suncana.roksandic@pravo.hr
}

\author{
Marta Dragičević Prtenjača, PhD, Assistant Professor \\ University of Zagreb, Faculty of Law \\ Trg Republike Hrvatske 14, Zagreb, Croatia \\ marta.dragicevic@pravo.hr
}

\begin{abstract}
The authors are addressing in the paper the (un)efficiency of the confiscation in Croatia. In order to fully implement confiscation of proceeds of crime, as the measure that guards property rights of the primary owner, is guardian of the principle of justice, and serves the protection of public interest, the authors are proposing three concrete amendments to existing regulation. In addition, the authors explained what protection of property encompasses, having in mind the sui generis character of this measure.
\end{abstract}

Keywords: confiscation proceeds of crime, non-conviction confiscation, confiscation from third persons

\section{INTRODUCTION}

Confiscation of proceeds of crime is the measure that guards property rights of the primary owner, it protects the principle of justice, and serves the protection of public interest. The right to property in Croatia is a Constitutional value ${ }^{1}$ (art. $3,48,50)$ protected also by Protocol 1 Art 1 of the European Convention of $\mathrm{Hu}$ -

Art. 3, 48 of the Consitution. Art. 50 of the Constitution which regulates the posibility of restiction of property rights -for more see Constitution of Republic of Croatia, Official Gazette, No. 56/1990, $135 / 1997,08 / 1998,113 / 2000,124 / 2000,28 / 2001,41 / 2001,55 / 2001,76 / 2010,85 / 2010,05 / 2014$ 
man Rights and Fundamental Freedoms (hereinafter: ECHR, Convention), ${ }^{2}$ and various laws in Croatia. ${ }^{3}$

The similar was underlined by the European Court of Human Rights (hereinafter: ECtHR, the Court), in case of Veits v Estonia: ${ }^{4}$ "The Court considers that confiscation in criminal proceedings is in line with the general interest of the community, because the forfeiture of money or assets obtained through illegal activities or paid for with the proceeds of crime is a necessary and effective means of combating criminal activities (see Raimondo v. Italy, 22 February 1994, J 30, Series A no. 281-A).... Thus, a confiscation order in respect of criminally acquired property operates in the general interest as a deterrent to those considering engaging in criminal activities, and also guarantees that crime does not pay ... ${ }^{5}{ }^{6}$

Understaning the legal nature of this measure is of paramount importance. There are two possible consequences depending on how the legal nature of confiscation of proceeds of crime is understood. If we consider the confiscation as a measure ad rem, we can confiscate the proceeds of crime from the third person and therefore, the measure should be considered as sui generis measure. Then, if we look at this measure ad personam, it is just another criminal sanction. In any case, since no one should benefit from committing criminal offence, which is one of main principles of the criminal law, the main purpose of this measure is not punishment, but restoring previous state of ownership by protecting property rights of real (primary) owner. Therefore, in this article, the authors argue and provide reason-

2 Protocol to the Convention for the Protection of Human Rights and Fundamental Freedoms; [https:// www.echr.coe.int/Documents/Convention_ENG.pdf] Accessed 20.03.2019, and Protocol to the Convention for the Protection of Human Rights and Fundamental Freedoms, Narodne novine, Međunarodni ugovori, br. 6/1999

3 E.g. Act on Ownership and Other Real Rights, Official Gazette, No 91/1996, 68/1998, 137/1999, 22/2000, 73/2000, 129/2000, 114/2001, 79/2006, 141/2006, 146/2008, 38/2009, 153/2009, 143/2012, 152/2014 and Criminal Code, Official Gazette, No 125/2011, 144/2012, 56/2015, $61 / 2015,101 / 2017,118 / 2018$. One old version of this act is available in English on: [http://pak.hr/ cke/propisi,\%20zakoni/en/OwnershipandOtherRealRights/EN.pdf] Accessed 20.03.2019

4 Judgment Veits v. Estonia (2015) par. 71 EHRR; [https://hudoc.echr.coe.int/eng\#\{\%22fulltext\%22:[\%22Veits\%20v\%20Estonia\%22],\%22itemid\%22:[\%22001-150303\%22]\}] Accessed 03.03.2019

5 For more see Judgment Denisova and Moiseyeva v. Russia, (2010) $\$ 58$, EHRR, [https://hudoc.echr. coe.int/eng\#\{\%22fulltext $\% 22:[\% 22$ Denisova $\% 20$ and\%20Moiseyeva\%22],\%22documentcollectionid2\%22:[\%22GRANDCHAMBER\%22,\%22CHAMBER\%22],\%22itemid\%22:[\%22001-98018\%22]\}] Accessed 03.03.2019, with further references to Judgement Phillips v. the United Kingdom, (2001) EHRR, par. 52., [https://hudoc.echr.coe.int/eng\#\{\%22fulltext\%22:[\%22Phillips\%20v.\%20 the\%20United\%20Kingdom\%22],\%22itemid\%22:[\%22001-59558\%22]\}] Accessed 03.03.2019

6 Vučko, M.; Šamota Galjer, M., Imovinski izvidi i privremene mjere osiguranja radi primjene instituta oduzimanja imovinske koristi ostvarene kaznenim djelom i prekršajem- Priručnik za polaznike/ice, Pravosdna Akademija, Zagreb; 2016, [http://pak.hr/cke/obrazovni\%20materijali/Imovinski\%20izvidi\%20i\%20privremene\%20mjere\%20osiguranja.pdf] Accessed 12.03.2019 
ing that the rules on confiscation from third person, or in case of the perpetrator's death, should be the same regradless of the type of implemented confiscation, i.e. ordinary or extended. In addition, in this article it is argued that the same should apply when the offence becomes statute barred, i.e. when staute of limitation elapses (including for privatization and ownership transformation crimes from the transitional period that are statute barred according to art. 31 para 4 . of the Croatian Constitution) . In addition, authors argue, by respecting that these rules should be, in principle, in line with civil law regulation (Civil Obligations Act ${ }^{7}$ ), and protect the third person's property if they acted in bona fide, in cases of transferring the proceeds of crime to family members this should not be the case.

Therefore, the confiscation of the proceeds of crime is an instrument that, besides its restorative nature, prevents illegal enrichment of perpetrators in accordance with the principle of justice. ${ }^{8}$ However, authors argue in the article that the institute itself must be understood and precisely and comprehensively regulated and effectively implemented in practice in order to satisfy the principle of legality and be in accordance with the rule of law. Hence, Tanzi, Quirk and Bartlet pointed out, "the efficient confiscation regime is needed to prevent the erosion of the rule of law."

Furthermore, particular question is what should Croatia do with confiscated and collected proceeds of crime that belong to state budget? The authors argue in the paper that it should be invested in social needs of population and enhancement of their human rights, besides investing in crime prevention.

Civil Obligations Act, Official Gazette, No. 35/2005, 41/2008, 125/2011, 78/2015, 29/2018

$8 \quad$ Horvatić, Ž., Kazneno pravo, Opći dio 1, Sveučilište u Zagrebu, Pravni fakultet, Zagreb 2003, p. 249

9 Cited in Ivičević Karas, E.; Roksandić Vidlička, S., The Relevence of Asset Recovery Policies in Transitional Societies: The Croatian Perspecitve in Chasing Criminal Money in: Ligeti, K.; Simonato, M. (eds.), Challenges and Perspectives On Asset Recovery in the EU, Hart, Oxford and Portland, Oregon, 2017, p. 19 referring to the article of Tanzi, Quirk and Boyle cited in van Duyne P., de Zanger W. and Kristen F.H:G., Greedy of crime-money The realitiy and ethics of asset recovery in: van Duyne et al. (eds), Corruption, Greed and Crme money: Slease and Shady Economy in Europe and Beyond, Wolf Legal Publishers, 2014, p. 235; Galiot, M.; Oduzimanje imovinske koristi međunarodne pravne stečevine i suzbijanja podmićivanja, Zbornik Pravnog fakulteta Sveučilišta u Rijeci. Vol. 38, No. 1, 2017, pp. 547-572 


\section{PROPERTY RIGHTS AS A PROTECTED RIGHT IN THE ECHR IN LIGHTS OF CONFISCATION AND REDISTRIBUTION OF PROCEEDS OF CRIME ${ }^{10}$}

In today's EU member states property is considered to be one of the key concepts of a legal order because "property is vital to society, since property and contracts jointly form the basis of exchange and trade, on which the market economy is built." ${ }^{11}$ According to Lavrysen, the right to property can actually be considered to be instrumental for the protection of the social right involved. It is listed in the prioritization of the protection of the right to property in cases where this is instrumental for the protection of other human rights. Moreover, the right to property is listed in the EU Charter of Fundamental Rights, based on article 1 of Protocol 1 of the ECHR; it is common to all national constitutions and has been recognized on numerous occasions by the case law of the Court of Justice, initially in the Hauer judgment. ${ }^{12}$ So as to reiterate that judgment, ${ }^{13}$ the right to property is guaranteed in the Community legal order in accordance with the ideas common to the constitutions of the member states, which is also reflected in the First Protocol to the Convention. Based on the judgments, "restrictions should correspond to objectives of general interest pursued by the Community and that with regard to the aim pursued, they should not constitute a disproportionate and intolerable interference with the rights of the owner, such as to impinge upon the very substance of the right." ${ }_{14}$

The right to property is not embodied in the ECHR itself ${ }^{15}$ but was added in its First Protocol and is enshrined in article 1 of Protocol 1 of the ECHR. ${ }^{16}$ The First

10 This Chapter is based upon research as published in Roksandić Vidlička, S., Prosecuting Serious Econimic Crimes as International Crimes, A New Mandate for the ICC?, Duncker\&Humblot, Berlin, 2017, Chapter: The Protection of Property as a Means to Achieve the Fulfilment of Economic and Social Rights - Some Comparison to other Regional Human Rights Mechanism, pp. 258-280, particulary see pp. 267-273

11 Icelandic Human Rights Center, The right to property report

12 Judgment of the Court of 13th December 1979. Case 44/79 Liselotte Hauer v. Land Rheinland-Pfalz. [1979] ECR, Reference for a preliminary ruling: Verwaltungsgericht Neustadt an der Weinstraße, Germany. Prohibition of new planting of vines. [https://eur-lex.europa.eu/legal-content/EN/TXT/ PDF/?uri=CELEX:61979CJ0044\&from=EN] Accessed 20.03.2019

13 Case 44/79 Liselotte Hauer v. Land Rheinland-Pfalz. [1979] ECR, par. 4

14 Case 44/79 Liselotte Hauer v. Land Rheinland-Pfalz. [1979] ECR, par 5

15 For more see The right to property - Introduction, [http://echr-online.info/right-to-property-article1-of-protocol-1-to-the-echr/introduction/] Accessed 20.03.2019; also see Bates, E., The Evolution of the European Convention on Human Rights: From its Inception to the Creation of a Permanent Court of Human Rights, Oxford, 2010

16 "(1) Every natural or legal person is entitled to the peaceful enjoyment of his possessions. No one shall be deprived of his possessions except in the public interest and subject to the conditions provided 
Protocol entered into force in 1954 . The right to property is among the most frequently violated Convention rights, third only to the right to speedy trial and the right to a fair trial. ${ }^{17}$

Therefore, article 1 of Protocol 1 protects individuals or legal persons from arbitrary interference with their possessions by the state and "is not concerned in general with relationships of a purely contractual nature between private individuals." 18 Nevertheless, by determining the "effects of legal relations between individuals on property, the ECtHR checks that the law did not create such inequality that one person could be arbitrarily and unjustly deprived of property in favor of another". ${ }^{19}$ As Grgic, Mataga et al. continue ${ }^{20}$ in certain circumstances, the state may be under an obligation to intervene in order to regulate the actions of private individuals. ${ }^{21}$

Regarding the Convention, in the first judgment concerning the property right in Marckx v. Belgium, ${ }^{22}$ the ECtHR defined the scope of the right as it applies only to existing possessions and does not guarantee the right to acquire more. ${ }^{23}$ This means that the protection of article 1 of Protocol 1 does not apply "unless and until" it is possible to lay a claim to certain property and does not guarantee the right to acquire property. ${ }^{24}$ The notion of a "possession" is broadly interpreted by the ECtHR and

for by law and by the general principles of international law. (2) The preceding provisions shall not, however, in any way impair the right of a State to enforce such laws as it deems necessary to control the use of property in accordance with the general interest or to secure the payment of taxes or other contributions or penalties." - The right to property - Introduction, [http://echr-online.info/right-toproperty-article-1-of-protocol-1-to-the-echr/introduction/] Accessed 20.032019

17 "As of 1st January 2010, 14.58\% of all judgments in which the European Court of Human Rights found a violation of the ECHR concerned the right to property; $26.37 \%$ regarded the length of proceedings and $21.10 \%$ the right to a fair trial under article 6 . - The right to property - Introduction, Introduction/Overview, Relevance, [http://echr-online.info/right-to-property-article-1-of-protocol-1to-the-echr/introduction/] Accessed 20.03.2019

18 Grgić, A.; Mataga, Z.; Longar, M.; Vilfan, A., The right to property under the Eureopan Convnetion on Human Rights: A guide to the implementation of the European Convnetion on Human Rights and its protocols. Human Rights Handbooks, No.10, Strasborug, 2007, p. 6

19 Ibid.

20 Ibid.

$21 \quad$ Ibid.

22 By recognizing that everyone has the right to the peaceful enjoyment of his possessions, article 1 is in substance guaranteeing the right of property. "The right to dispose of one's property constitutes a traditional and fundamental aspect of the right of property".- Judgment Marckx $v$. Belgium (1979), EHRR, par. 63., [https://hudoc.echr.coe.int/eng\#\{\%22fulltext\%22:[\%22Marckx\%20v.\%20 Belgium\%22],\%22itemid\%22:[\%22001-57534\%22]\}] Accessed 26.03.2019

23 Underlined by Grgić et al., op. cit., note 18, p. 7

24 Carss-Frisk, M. The right to property, A guide to implementation of article 1 of the Protocol No.1. to the European Convention on Human Rights, Human Rights Handbooks, No. 4, The Council of Europe, 2001, p. 6; Grgić et al., op. cit., note 18, p. 7 
covers a range of economic interests, such as movable or immovable property, tangible or intangible interests (such as shares, patents, an arbitration award, the entitlement to a pension, the right to exercise a profession, etc.). ${ }^{25}$ Interesting examples on property decisions in this respect can be found in the jurisprudence of The Human Rights Chamber for Bosnia and Herzegovina, although by 2003, it ceased to function. According to the Chamber, such a right is a "valuable asset" that "constitutes a 'possession' within the meaning of Article 1 as interpreted by the European Commission and Court." ${ }^{26}$

Article 1 "sought to ensure that any interference with property rights pursues the general or public interest." ${ }^{27}$ In particular, public authorities can control the use of property to secure the payment of taxes or other contributions, or penalties. Hence, in order to comply with the test of proportionality between the collective interest and the interests of an individual, interference should be conducted in such a manner which is not arbitrary and which is in accordance with the law. Regarding its necessity, however, "the ECHR ... has generally accorded states a wide margin of appreciation". ${ }^{28}$ As Grgić, Mataga et al. continue, ${ }^{29}$ although article 1 of Protocol 1 contains no explicit reference to a right to a compensation for having one's property taken or another interference, ${ }^{30}$ this is implicitly required in practice. ${ }^{31}$

The content of the right (article 1 of Protocol 1) comprises three distinct rules for protection. This analysis was first put forward in the case of Sporrong and Lönnroth $v$. Sweden,,$^{32}$ which is one of the most important ECtHR judgments related to this Convention article. ${ }^{33}$ The first rule is general and states the peaceful enjoyment of

25 Grgić et al., op. cit., note 18, p. 7

26 UN Human Rights Office of the High Commissioner Publication on Transitional Justice and Economic, Social and Cultural Rights 2014, pp. 28-29, [https://www.ohchr.org/Documents/Publications/HR-PUB-13-05.pdf] Accessed 26.03.2019; Grgić et al., op. cit., note 18, p. 7

27 Grgić et al., op. cit., note 18, p. 5

28 Ibid.

29 Ibid.

30 The same was stated in Harris, D. J.; O’Boyle, M.; Warbick, C.; Bates, E.; Buckly, C., Law of the European Convention on Human Rights, Oxford University Press, Oxford 2014, p. 862

31 Referring to the case Holy Monasteries v. Greece. Judgment Holy Monasteries v. Greece (1997) EHRR 50, [https://hudoc.echr.coe.int/eng\#\{\%22fulltext\%22:[\%22Holy\%20Monasteries\%20v.\%20Greece\%22] ,\%22itemid\%22:[\%22001-58180\%22]\}] Accessed 26.03.2019. The same was stated in Harris et al, op. cit., note 30 , p. 862

32 Judgment Sporrong and Lönnroth v. Sweden (1984) EHRR 50, [https://hudoc.echr.coe.int/eng\#\{\%22fulltext\%22:[\%22Sporrong\%20and\%20L\%C3\%B6nnroth\%20v.\%20Sweden\%22],\%22itemid\%22:[\%22001-57579\%22]\}] Accessed 26.03.2019

33 Grgić et al., op. cit., note 18, p. 10 
the property. The second rule covers the deprivation of possessions $s^{34}$ and subjects it to certain conditions. The third rule recognizes that states are entitled to control the use of property in accordance with general interest. The last two rules must be interpreted in light of the general principle laid down in the first one. ${ }^{35}$ Each of these rules corresponds to a different type of interference, which includes an interference justified by the need to secure payment of taxes or other contributions or penalties. ${ }^{36}$ It must be emphasized that with respect to the control of the property (third rule), the ECtHR sets standards of proportionality at a lower level, consequently allowing for a wider margin of appreciation to states than in cases related to deprivation or expropriation (second rule). ${ }^{37}$

The right to property is not absolute and is subject to restrictions, but interference $^{38}$ should only be allowed if it is prescribed by law; this is in the interest of the public and necessary in a democratic society. ${ }^{39}$ All three conditions must be fulfilled cumulatively, and "should only one of them not be met, there will have been a violation of the Convention". ${ }^{40}$ In contrast to articles 8 to 11 of the ECHR, article 1 of Protocol 1 does not contain a catalogue of objectives to justify interferences. On a case-by-case basis, the Court ascertains whether the interference with the right to property pursues a legitimate aim. Member states enjoy a wide margin of appreciation when deciding which aim is legitimate.

Moreover, as in other cases, the ECtHR has established three main principles for the protection of property. Those are the principle of lawfulness, ${ }^{41}$ the principle of

34 As stated, 'property and possessions' has a very wide meaning under article 1 of Protocol 1, including, but not limited to, physical goods, land and contractual rights, pension entitlements, shares, and patents. In some circumstances, the protection extends to corporate bodies as well as individuals.- Equality and Human Rights Commission, The First Protocol The First Protocol to the European Convention on Human Rights contains three further fundamental rights in Human Rights Review 2012 How fair is Britain? An assessment of how well public authorities protect human rights, p. 424, [https://www. equalityhumanrights.com/sites/default/files/human-rights-review-2012.pdf] Accessed 26.03.2019

35 Human rights files, No. 11 rev. The European Convention on Human Rights and Property Rights by Laurent Sermet Professeur, University of La Réunion, Conceil d'Europe 1999, p. 8, [https://www.echr. coe.int/LibraryDocs/DG2/HRFILES/DG2-EN-HRFILES-11(1998).pdf] Accessed 26.03.2019

36 Judgment Sporrong and Lönnroth v. Sweden (1984), EHRR 50, par. 61

37 Christophe Golay, C.; Cismas, I; Legal Opinion: The Right to Property from a Human Rights Perspective 2010, p. 15, citing Arai-Takahashi, Y., The Margin of Appreciation Doctrine and the Principle of Proportionality in the Jurisprudence of the ECHR, Antwerp et al., 2002, p.148

38 See e.g. Judgment Beyeler v. Italy (2000) EHRR

39 Grgić et al., op. cit., note 18, p. 12

40 Ibid.

41 Interference with the right to property must satisfy the requirement of legality and legal certainty. "The Act must ... contain certain qualitative characteristics and afford appropriate procedural safeguard so as to ensure protection against arbitrary action" (Grgić et al., op. cit. note 18, p. 13). For instance, in the case of James $v$. The United Kingdom, the ECtHR reiterated that "it has consistently held that the terms 
a legitimate aim in the general (public) interest, and the principle of a fair balance (proportionality). The ECtHR has reiterated as the most important requirement of article 1 of Protocol 1 that any interference by a public authority with the right to peaceful enjoyment of possessions should be lawful. ${ }^{42}$ This legal basis has to be sufficiently accessible, precise and foreseeable. . $^{3}$

The interference with the right to property has to pursue a legitimate aim in the general (public) interest: deprivations of property are only allowed if they are in the public interest, thus the control and use of the property has to be in accordance with general interest. ${ }^{44}$ The limitations on rights foreseen in the Convention may only be used to the ends to which they are prescribed. ${ }^{45}$ As stated above, the notion of "public interest" is understood to be an extensive one, and the ECtHR "respects the domestic authorities' judgment as to what is in the "public interest" unless the judgment is manifestly without reasonable foundation." ${ }^{46}$

Last but not least, the principle of proportionality requires that the interests of the affected individual, by measure of interfering with the right to property, has to be acknowledged in the interest of the general public. The interference must not impose an excessive or disproportionate burden on the individual. ${ }^{47}$ As already stated, state authorities are "better placed" to assess the existence of both interests, "given their direct contact with the social process forming the country"; but the ECtHR "shall certainly take into account the existence of alternative solutions when ruling whether interference has been proportionate to the aim sought to be achieved as in other applicable cases, as well as in property cases.” 48 In any event, "a fair balance between the demands of the general interest of the community

"law" or "lawful" in the Convention (do) not merely refer back to the domestic law but also [relate] to the quality of law, requiring it to be compatible with the rule of law" (Grgić et al., op. cit., note 18, p. 13)

42 Judgment Saliba et al. v. Malta (2013) EHRR, par. 37., [https://hudoc.echr.coe.int/eng\#\{\%22fulltext\%22:[\%22Saliba\%20\%20v\%20Malta\%22],\%22itemid\%22:[\%22001-116073\%22]\}] Accessed 20.03.2019

43 For more see The right to property - Introduction, [http://echr-online.info/right-to-property-article1-of-protocol-1-to-the-echr/introduction/] Accessed 20.03.2019

44 Grgić et al., op. cit., note 18, p. 13

45 Judgment Beyeler v. Italy (2000) EHRR, par. 111

46 Grgić et al., op. cit., note 18, p. 14

47 Judgment Valkov et al. v. Bulgaria (2011) EHRR, par. 79, 80, 84-91., [https://hudoc.echr.coe.int/eng\#\{\%22fulltext\%22:[\%22Valkov\%22],\%22itemid\%22:[\%22001-107157\%22]\}] Accessed 20.03.2019

48 Grgić et al., op. cit., note 18, p. 14-15 
and the requirements of the protection of the individual's fundamental rights" ${ }^{39}$ is explored.

As stated, the main purpose of the confiscation of proceeds of crime is not punishment, but restoring previous state of ownership by protecting property rights of real (primary) owner. Therefore, according to the authors' opinion, confiscation of the proceeds of crime protects the rights of rightful (primary) owner.

In addition, particular attention should be given to the proportionality requirement regarding freezing the real estate or other property. In that contexts in case Džinić v Croatia (2016) the ECtHR found that there has been a violation of Art. 1. of the Protocol no. 1 to the Convention (Peaceful enjoyment of property rights) in conjunction with Art. 13. of the Convention (Right to an effective remedy). ${ }^{50}$ In mentioned case Vukovar's County State Attorney's Office froze and seized the applicant's real property and register that restrain in the land registry, but the value of the restrained real property was disproportionate of the alleged pecuniary gain, so ECHR found that Croatia has violated applicant's property rights.

\section{CONFISCATION IN CROATIA}

In Croatia the confiscation of proceeds of crime is considered as independent and individual sui generis measure regulated with two main laws: the Criminal Code (hereinafter: CC) ${ }^{51}$ and Criminal Procedural Act (hereinafter: CPA). ${ }^{52}$ Additional issues relating confiscation are regulated within several other codes: the Law on the Office for Prevention of Corruption and Organized Crime (hereinafter: LOPC), ${ }^{53}$ the Law on the Liability of Legal Persons for Criminal Offenses (hereinafter: LLLPCO) $)^{54}$ and the Law on Mutual Legal Assistance in Criminal Matters

\footnotetext{
49 Judgment Tre Traktörer Aktiebolag v. Sweden (1989), EHRR, par. 46., [https://hudoc.echr.coe. int/eng\#\{\%22fulltext\%22:[\%22Tre\%20Trakt\%C3\%B6rer\%20Aktiebolag\%22],\%22itemid\%22:[\%22001-57586\%22]\}] Accessed 27.03.2019

50 Judgment Džinić v Croatia (2016) EHRR, [https://hudoc.echr.coe.int/eng\#\{\%22fulltext\%22:[\%22D\%C5\%BEini\%C4\%87\%22],\%22itemid\%22:[\%22001-162868\%22]\}] Accessed 27.03.2019

51 Criminal Code, Official Gazette, No. 125/2011, 144/2012, 56/2015, 61/2015, 101/2017, 118/2018. Croatia got its new Criminal Code in 2011, and it entered into force in 2013

52 Criminal Procedural Act, Official Gazette, No. 152/2008, 76/2009, 80/2011, 91/2012, 143/2012, 56/2013, 145/2013, 521/2014,70/2017 (art 556-563)

53 The Law on the Office for Prevention of Corruption and Organized Crime, Official Gazette, No. 76/2009, 116/2010, 145/2010, 57/2011, 136/2012, 148/2013 (art 50-61)

54 Law on the Liability of Legal Persons for Criminal Offenses, Official Gazette, No. 151/2003, 110/2007, $45 / 2011,143 / 2012$
} 
(hereinafter: LMLACM). ${ }^{55}$ A special law, the Act on Proceedings of Confiscation of Pecuniary Gain Acquired through a Criminal Offence and Misdemeanors, that entered into force in 2010 and was abolished in 2017, was the main source of regulation of procedural matters. In 2017, CPA took over this task. ${ }^{56}$

The United Nations Convention against Corruption (hereinafter: UNCAC) ${ }^{57}$ (art. $51)^{58}$ had influence of the regulation of this institute, especially extended confiscation. As further elaborated by Moiseienko, ${ }^{59}$ Article 51 of the UNCAC proclaims the return of assets diverted through corruption to be a 'fundamental principle' of the Convention. ${ }^{60}$ Furthermore, rules on confiscation found in the UNCAC, the UN Convention against Transnational Organized Crime (UNCTOC) ${ }^{61}$ and the (non-binding) Recommendations of the Financial Action Task Force (FATF) ${ }^{62}$ as well as other different international conventions, ${ }^{63}$ conventions and regulations of

55 The Law on Mutual Legal Assistance in Criminal Matters, Official Gazette, No. 178/2004

56 The Act on Proceedings of Confiscation of Pecuniary Gain Acquired through a Criminal Offence and Misdemeanours Official Gazette, No. 145/2010, 70/2017 which was abolished in 2017, and all of its regulations were placed in Criminal Procedural Code Art. 556-563

57 United Nations Convention against Corruption, 2003., [https://www.unodc.org/documents/brussels/ UN_Convention_Against_Corruption.pdf] Accessed 27.03.2019

58 Also see Article 31(1) UNCAC

59 Moiseienko, A., The ownership of confiscated proceeds of corruption under the un convention against corruption, International and Comparative Law Quarterly Q, Vol. 67, July 2018, pp 669-694, p. 669, [https://www.cambridge.org/core/services/aop-cambridge-core/content/view/2C0108B5CB28B75294D9C10257F17653/S002058931800012Xa.pdf/ownership_of_confiscated_proceeds_of_corruption_under_the_un_convention_against_corruption.pdf] Accessed 27.03.2019

60 "The return of assets pursuant to this chapter is a fundamental principle of this Convention, and States Parties shall afford one another the widest measure of cooperation and assistance in this regard". -Art 51 UNCAC

${ }^{61}$ United Nations Convention against Transnational Organized Crime and the Protocols Thereto, [https://www.unodc.org/unodc/en/organized-crime/intro/UNTOC.html] Accessed 27.03.2019

62 FATF, International Standards on Combating Money Laundering and the Financing of Terrorism \& Proliferation: The FATF Recommendations (October 2002, updated June 2017), [http://www.fatfgafi.org/media/fatf/documents/recommendations/pdfs/FATF\%20Recommendations\%202012.pdf] Accessed 27.03.2019

63 United Nations Convention against Illicit Traffic in Narcotic Drugs and Psychotropic Substances, 1988, [https://www.unodc.org/pdf/convention_1988_en.pdf] Accessed 27.03.2019; International Convention for the Suppression of the Financing of Terrorism, 1999, [https://www.unodc.org/documents/treaties/Special/1999\%20International\%20Convention\%20for\%20the\%20Suppression $\% 20$ of $\% 20$ the $\% 20$ Financing\%20of\%20Terrorism.pdf] Accessed 27.03.2019; United Nations Convention against Transnational Organized Crime, 2000, [https://www.unodc.org/documents/middleeastandnorthafrica/organised-crime/UNITED_NATIONS_CONVENTION_AGAINST_TRANSNATIONAL_ORGANIZED_CRIME_AND_THE_PROTOCOLS_THERETO.pdf] Accessed 27.03.2019.; United Nations Convention against Corruption, 2003 
the Council of Europe (CoE) ${ }^{64}$ and regulations and EU Directive ${ }^{65}$ of European Union (hereinafter: EU) ${ }^{66}$ have influenced Croatian legislation on confiscation of proceeds of crime.

However, one should be reminded, the confiscation of proceeds of crime as independent and individual measure sui generis was not unknown in Croatia before its independence in 1990 and before mentioned EU, CoE and international regulation became incorporated in Croatian legislation. It was introduced as independent, however a security measure already in $1959^{67}$ with amendments of the 1951 Criminal Code. It came into force in $1960 .{ }^{68}$ Even until 1959 confiscation existed, but it was regulated in different laws containing particular criminal offences (e.g. active and passive bribery). ${ }^{69}$ The status of this measure as security measure lasted until 1977, until confiscation had a character of criminal law sanction and status of security measure. ${ }^{70}$ After this period its legal status changed and was no longer considered as a security measure. ${ }^{71}$ It got a status as special independent measure (sui generis). The confiscation of pecuniary gain was again regulated in the new

64 Council of Europe Convention on Laundering, Search, Seizure and Confiscation of the Proceeds from Crime, 1990., [https://www.coe.int/en/web/conventions/full-list/-/conventions/treaty/141] Accessed 27.03.2019; Criminal Law Convention on Corruption, 1999, [https://www.coe.int/en/web/ conventions/full-list/-/conventions/treaty/173] Accessed 27.03.2019; Council of Europe Convention on Laundering, Search, Seizure and Confiscation of the Proceeds from Crime and on the Financing of Terrorism, 2005, [https://www.coe.int/en/web/conventions/full-list/-/conventions/treaty/198] Accessed 27.03.2019; Council of Europe Convention on the Prevention of Terrorism, 2005, [https:// www.coe.int/en/web/conventions/full-list//conventions/treaty/196] Accessed 27.03.2019

65 Directive 2014/42/EU of the European Parliament and of the Council of 3 April 2014 on the freezing and confiscation of instrumentalities and pecuniary gain in the European Union [2014] L 127/39

66 Council Framework Decision 2001/500/JHA of 26 June 2001 on Money Laundering, the Identification, Tracing, Freezing, Seizing and Confiscation of Instrumentalities and the Proceeds of Crime [2001] OJ L182/1.; Council Framework Decision 2003/577/JHA of 22 July 2003 on the execution in the European Union of orders freezing property or evidence, [2003] OJ L-196/45; Council Framework Decision 2005/212/JHA of 24 February 2005 on Confiscation of Crime-Related Proceeds, Instrumentalities and Property [2005] L 68/49. Council Framework Decision 2008/841/JHA of 24 October 2008 on the fight against organised crime [2008] L 300/42

67 Petranović M., Oduzimanje imovinske koristi ostvarene kaznenim djelom; [www.vsrh.hr/CustomPages/.../MPetranovic-Oduzimanje_imovinske_koristi_ostv.doc] Accessed 01.03.2019

68 Kaleb, Z., Novo uredenje instituta oduzimanja imovinske koristi prema noveli Kaznenog zakona sosvrtom na dosadašnju sudsku praksu - usporedba s odlukom o imovinskopravnom zahtjevu, Hrvatski ljetopis za kazneno pravo i praksu (Zagreb), Vol. 10, No. 2, 2003, p. 450.

69 Ibid.

70 Ibid.

71 As stated by Horvatić, confiscation of pecuniary gain is not security measure nor criminal sanction, but the consequence of the principle of justice Horvatić, Ž.; Novoselec, P., Kazneno pravo - opći dio, Zagreb, 2001, p. 474; also see Horvatić, op.cit., note 8, p. 249 
Criminal Code of Croatia in 1997 (hereinafter: CC 97$)^{72},{ }^{73}$ after Croatia ratified the Council of Europe's Convention on Laundering, Search, Seizure and Confiscation of the Proceeds from Crime. ${ }^{74,75}$ Amendments of 2008 to CC97 introduced additionally new form of extended confiscation. ${ }^{76}$

As stated by Ivičević Karas and Roksandić Vidlička ${ }^{77}$ among academics, there have been discussions about other possible models of efficient confiscation even prior to 2010 political and legislative initiatives. ${ }^{78}$ The reason was that traditional regime of confiscation was not an efficient solution for the new forms of crime particularly serious economic crime, corruption and organized crime. Also in practice, the confiscation was rarely pronounced despite the fact that the main motivation of perpetrators of economic crimes was acquiring unlawful pecuniary gain. ${ }^{79}$ Because of all the mentioned above, as well as to comply with European and international obligations, it was necessary to reform the confiscation regime, and, among amendments, introduce the extended confiscation and new models of confiscation. Beside conviction based confiscation, also the non-conviction based confiscation was introduced.

Today we have two main models in Croatian criminal law - conviction based and non- conviction based confiscation. Usually there has to be a conviction for confiscation of proceeds of crime, but in some cases there is also possibility of confiscation when there is no conviction- non-conviction based confiscation (see more in par. 3.2). Both of the models are applicable for both types of confiscation - ordinary and extended.

Therefore, provisions on confiscation of pecuniary gain acquired through criminal offences are among the most frequently amended provisions of former Criminal

72 Criminal Code, Official Gazette, No 110/1997, 27/1998, 50/2000, 129/2000, 84/2005, 51/2001, 111/2003, 190/2003, 105/2004, 71/2006, 110/2007, 152/2008, 57/2011, 77/2011

73 Novoselec, P, Opći dio kaznenog prava, Osijek, 2016, p. 458

74 Convention on Laundering, Search, Seizure and Confiscation of the Proceeds from Crime. ETS No. 141 i Narodne novine, Međunarodni ugovori 14/1997

75 See more in Kos, D., Problematika oduzimanja imovinske koristi, Hrvatski ljetopisa za kazneno pravo i praksu, Vol. 5, No. 2, 1998, str. 757

76 Art. 82 para 2. CC97-Amenedends of CC97 Official Gazette, No 152/2008, art. 2

77 Ivičević Karas, E.; Roksandić Vidlička, S., The Relevence of Asset Recovery Policies in Transitional Societies: The Croatian Perspecitve, in: eds. Ligeti, K.; Simonato, M. (eds.), Chasing Criminal Money - Challenges and Perspectives On Asset Recovery in the EU, Hart, Oxford and Portland, Oregon, 2017, pp. 243-244

78 See generally Elizabeta Ivičević, Oduzimanje imovinske koristi stečene kaznenim djelom, Hrvatsko udruženje za kaznene znanosti i praksu, Ministarstvo unutarnjih poslova RH, Zagreb 2004, pp. 170173

79 Ivičević Karas; Roksandić Vidlička, op. cit. note 77, pp. 243-244 
Code, and of the new Criminal code which is in force since $2013 .{ }^{80}$ As stated by Kurtovic in 2000, ${ }^{81}$ repeated by Kaleb in $2003,{ }^{82}$ the expansion of various forms of crime led to amendments of this institute, however practical application of this measure is far from effective.

On the other hand, applicability and efficiency of this measure is far from perfection, and therefore, the regulation of confiscation of proceeds of crime is always a "contemporary" topic in the Croatian society. ${ }^{83}$ Therefore, this measure as an independent measure exists 60 years in Croatia ${ }^{84}$ but it seems that its full efficiency and effectiveness is still waited.

Following the EU and the above mentioned international documents (e.g. UN$\mathrm{CAC}$ ), one of the main principles of Croatian criminal law is that no one can benefit from the committed criminal offense. Croatian Criminal Code explicitly regulated this principle in the Art. 5 . of the $\mathrm{CC}:{ }^{85}$ no one may retain a pecuniary gain acquired through illegal means, or that "crime does not pays off." 86

In any case, at this point, Criminal Code regulates, two main categories of confiscation of proceeds of crime: ordinary and extended confiscation. Accordingly, CC defines what is considered as proceeds of crime, as well as property in the criminal law context and has specified the notions of direct and indirect pecuniary gain. Those definitions are harmonized with the relevant international and regional conventions and the EU regulations. ${ }^{87}$ Direct pecuniary gain is "any advantage

\footnotetext{
80 Ibid.

81 Kurtović, A., Zakonska rješenja u svijetlu primjene mjera upozorenja, sigurnosnih mjera i oduzimanja imovinske koristi, Hrvatski ljetopis za kazneno pravo i praksu, Vol. 7, No. 2, 2000., pp. 369-370. Also see Kos, op. cit., note 75, p. 757

82 Kaleb, op. cit. note 67, p. 450

83 Bačić, F., Kazneno pravo -opći dio, V. izdanje, Zagreb, 1998, pp. 470-471; Kos, op. cit. note 75, p. 757; Kurtović, op. cit. note 80, pp. 369-370; Ivičević Karas, E., Zakon o postupku oduzimanja imovinske koristi ostvarene kaznenim djelom i prekrš́ajem: neka otvorena pitanja i moguća rješenja, Hrvatski ljetopis za kazneno pravo i praksu, 2011, pp. 557-578; Ivičević, E., Oduzimanje imovinske koristi stečene kaznenim djelom, Hrvatsko udruženje za kaznene znanosti i praksu Ministarstva unutarnjih poslova Republike Hrvatske, Zagreb, 2004, p. 94; Horvatić, Ž., Novoselec, P., Kazneno pravo - opći dio, Zagreb, 2001, p. 463

84 This institute has its roots in the Criminal Code of Norway form 1902, see Galiot, op cit., note 9, p. 559 , fn. 59

85 Principle of Confiscation of Pecuniary Advantage (proceeds of crime)- „No one may retain a pecuniary advantage acquired through illegal means"- art. 5 CC

86 Ivičević Karas; Roksandić Vidlička, op. cit., note 77, pp. 243-244

87 See footnote $(57,60-66)$
} 
which occurred by commission of the criminal offense"s8 and indirect is "the property in which direct pecuniary gain is altered or turned into, and any other benefit which derives from direct pecuniary gain or property to which direct pecuniary gain is changed or turned into. "ro

The notion of property is also defined in the CC (Art. 87, $\$ 23$ ): "property of any kind regardless of whether is tangible or intangible, movable or immovable, or are documents or legal instruments evidencing title to or interest in such property." Direct and indirect proceeds of crime, can be confiscated in ordinary way (ordinary confiscation) or through extended confiscation.

Ordinary confiscation is regulated in Art. 77. CC and extended in Art. 78. CC. Ordinary confiscation refers to pecuniary gain which originates from criminal offenses on the basis of a court decision establishing the commission of an unlawful act. ${ }^{90}$ Extended confiscation is applied when criminal offences within the jurisdiction of the Office for Prevention Corruption and Organized Crime (subsequently: USKOK $)^{91}$ have been committed as well in cases of sexual exploitation of the child and in the cyber-crimes cases. ${ }^{92}$ If the proceeds of crime gained from a criminal offence has been merged into legitimately acquired property, total property shall be subject to confiscation up to the estimated value of pecuniary advantage. The advantage gained from property in which the legitimately acquired property was merged with the pecuniary advantage gained from a criminal offence shall also be confiscated in the same manner and in the same ratio. ${ }^{93}$ So distinction is not only in conditions, but also in manner of their application, and in the burden of proof.

\subsection{Burden of proof in cases of the extended confiscation}

The characteristic of the extended confiscation is the inversion of the burden of proof to the perpetrator. Once the prosecutor (USKOK) shows (proofs) that property owned by perpetrator is incommensurate with his/her legitimate income, the

88 Art 87, \$22 CCC

In 2018 definition of pecuniary gain has been changed, especially definition of direct pecuniary gain and expression "..which consists of any increase or prevention of reduction of property.." has been deleted form the definition. The definition of direct pecuniary gain before the amendnements stipulated “... which occurred by commission of the criminal offense any advantage which consists of any increase or prevention of reduction of property, which occurred by commission of the criminal offense"

89 Art 87, \$22 CCC

90 Art $77 \$ 1$ CCC

91 The Law on Office for Prevention Corruption and Organized Crime, Official Gazette, No 76/2009, $116 / 2010,145 / 2010,57 / 2011,136 / 2012,148 / 2013,70 / 2017$

92 Art. 78 CC

93 Art $78 \$ 3$ CCC 
burden of proof shifts to the perpetrator. He or she must make it probable that the mentioned property is of legitimate origin. If the perpetrator does not succeed, it is assumed his property represents "proceeds of crime:" If the perpetrator of a criminal offence within the competence of the Office for the Prevention of Corruption and Organized Crime owns or owned property that is incommensurate with his/her legitimate income and unless he/she makes it probable that the property is of legitimate origin, it is assumed that this property represents a pecuniary advantage gained from a criminal offence. ${ }^{94}$ This legal solution was introduced in the Croatian criminal law under the influence of the international documents, primarily the UNCAC. Since this Convention is widely accepted, what reflects its importance, majority of the member states have introduced into their national legislation provisions of extended confiscation of pecuniary gain (Germany, Italy, Netherland, Spain, Austria, Finland etc.). ${ }^{95}$ This legal reasoning was put under scrutiny of the ECHR. ECHR was dealing with the inversion of burden of proof in cases of extended confiscation especially whether it breaches the right to a fair trial (Art 6. ECHR). However, in Salabiaku v France, ${ }^{96}$ Phillips v UK, ${ }^{97}$ and Grayson \& Barnham $v U K,{ }^{98} \mathrm{ECtHR}$ found no violation of art. 6 of the Convention.

According to the practice of the ECtHR it can be concluded that the inversion of burden of proof as possible reduction of the standard of proof in criminal proceedings as well as in cases of confiscation of proceeds of crime are not contrary per se to the presumption of innocence and right to fair trail, but that has to be determine in concerto, on case to case basis. ${ }^{99}$

$94 \quad$ Art $78 \$ 2 \mathrm{CC}$

95 See Boroi, A., Elements of Comparative Law on Extended Confiscation, EIRP Proceedings, 2014 and Vettori, B.; Zanella, M., Going beyond the confi scation of proceeds from organised crime activities: Stripping away ill-gotten gains from corruption in the enlarged Europe, Apeldoorn, NL, 2011, pp. $271-290$

96 Judgment Salabiaku v France (1988) EHRR, par. 26, 27, [https://hudoc.echr.coe.int/eng\#\{\%22fulltext $\% 22:[\% 22$ Salabiaku\%20v\%20France\%22],\%22itemid\%22:[\%22001-57570\%22]\}] Accessed 10.03.2019

${ }^{97}$ Judgment Phillips $v$ UK (2001) EHRR, par. 33, [https://hudoc.echr.coe.int/eng\#\{\%22fulltext\%22:[\%22Phillips\%22],\%22itemid\%22:[\%22001-59558\%22]\}] Accessed 10.03.2019

98 Judgment Grayson \& Barnham v UK (2008) EHRR, par. 37-41, 45-50, [https://hudoc. echr.coe.int/eng\#\{\%22fulltext $\% 22$ : [\%22Grayson \%20\&\%20Barnham\%22], \%22itemid\%22:[\%22001-88541\%22]\}] Accessed 10.03.2019

99 Ivičević Karas, E. (a), Komentar Zakona o postupku oduzimanjima imovinske koristi ostvarene kaznenim djelom i prekršajem, Narodne novine, Zagreb, 2011, p. 28, 29; also see Ivičević Karas, E. (b), Zakon o postupku oduzimanja imovinske koristi ostvarene kaznenim djelom i prekršajem: neka otvorena pitanja i moguća rješenja, Hrvatski ljetopis za kazneno pravo i praksu Zagreb, Vol. 18, No. 2, 2011, pp. 557-578. There was different conclusion of the ECHR in case Geerings $v$ Netherlands (2007), EHRR, par. 36, [https://hudoc.echr.coe.int/eng\#\{\%22fulltext\%22:[\%2230810/03\%22],\%22itemid\%22:[\%22001-79657\%22]\}] Accessed 10.03.2019 


\subsection{Non-conviction based confiscation}

As a rule, it is necessary to have a conviction (conviction based confiscation). However, there is possibility of the confiscation of proceeds of crime based on the judgment by which the court established that the defendant committed the unlawful act that is the subject of the charge (e.g. in cases when the mentally incapable person has committed the act, who is not able for guilt). ${ }^{100}$ This possibility is known as the non-conviction based confiscation; ${ }^{101}$

There is also special sort of non-conviction based confiscation in relation to proceeds of unlawful acts when criminal prosecution cannot be carried out because of the existence of relevant circumstances, especially if the person against whom the criminal proceeding has been instituted is permanently unfit to plead or unavailable to the authorities participating in the criminal proceeding if it is probable that those proceeds amount to at least HRK 60,000.00. ${ }^{102}$

In such cases so called determining decision is rendered - a judgement determining that the person committed an unlawful act and that that act generated proceeds. ${ }^{103}$ Also in cases of non-conviction based confiscation proceeds of crime can be confiscated form third persons as well. ${ }^{104}$ This possible is recognized also outside of the EU. In United States (hereinafter: US) when person is fugitive from justice in a criminal case that is pending as Cassella notes "to obtain a forfeiture order without being able to obtain a conviction, the government had to file a non - convictionbased confiscation" 105 and the toll which makes it possible is so called "Fugitive Disentitlement Doctrine'. ${ }^{106}$

\subsubsection{Perpetrators death}

Moreover, another special sort of non-conviction based confiscation is proscribed for extended confiscation in case of perpetrators death (ar. 78 CC). In such cases when the person against whom criminal proceedings have been instituted dies, the proceeds of crime by an unlawful act may be confiscated from his/her successors in

\footnotetext{
100 See art. $560 \$ 1 \mathrm{CPA}$

101 For similar solutions of non-conviction based confiscation especially in United States see Cassella, Stefan D. The American Perspective on Recovering Criminal Proceeeds in Criminal and Non-Conviction Based Proceedings, in: Ligeti, K.; Simonato, M. (eds.), Chasing Criminal Money - Challenges and Perspectives On Asset Recovery in the EU, Hart, Oxford and Portland, Oregon, 2017, pp. 255-269

102 Art. 560a \$1 CPA

103 Art. 560.d \$ 1 CPA

104 art. 560.a $\$ 5 \mathrm{CPA}$

105 Stefan, op. cit. note 101 , p. 264

106 Ibid.
} 
proceedings prescribed in $\mathrm{CPC}$ if it is probable that amount of proceeds of crime is at least HRK 60,000.00. ${ }^{107}$

But it is not clear could proceeds of crime be confiscated in cases of perpetrators death when ordinary confiscation is in question. The CC nor CPA are silent on this matter. CC only regulates the situation of perpetrators death when extended confiscation should be imposed. ${ }^{108}$

Therefore, following the legal reasoning based on the argumentum a maiore ad minus, ${ }^{109}$ if the extended confiscation is possible from perpetrators' successors after perpetrators death, then it should be possible also for ordinary confiscation. However, the strict interpretation of CC provisions in art. 77 and 78 could lead to different solution. Art $77 \mathrm{CC}$ (which regulates ordinary confiscation) does not mention perpetrator's death.

By this reasoning, after perpetrator's death proceeds of crime gained by an unlawful act may not be confiscated from his/her successors if ordinary confiscation is in place.

However, the occurrence of death is not mentioned as such for non - conviction based confiscation in the Directive 2014/42/EU of the European Parliament and of the Council on the freezing and confiscation of instrumentalities and pecuniary gain in the European Union (subsequently: Directive). It is however, proscribed in art. 4 of the Directive that Member States shall take the necessary measures to enable the confiscation, either in whole or in part, of instrumentalities and proceeds or property the value of which corresponds to such instrumentalities or proceeds, subject to a final conviction for a criminal offence, which may also result from proceedings in absentia. Where such confiscation is not possible, at least where such impossibility is the result of illness or absconding of the suspected or accused person, Member States shall take the necessary measures to enable the confiscation of instrumentalities and proceeds in cases where criminal proceedings have been initiated regarding a criminal offence which is liable to give rise, directly or

107 Art $78 \$ 6$ CC and Art 560.f CPA: "If the person against whom criminal proceedings have been instituted dies, the pecuniary advantage gained by an unlawful act may be confiscated from his/her successors in proceedings prescribed by a special act”. - Art $78 \$ 6$ CCC

108 Art $78 \$ 6$ CC

109 See Horvatić, Ž; Derenčinović, D.; Cvitanović, L., Kazneno pravo opći dio 1., kazneno pravo i kazneni zakon, Pravni fakultet Sveučilišta u Zagrebu, Zagreb, 2016, p. 131, also see Novoselec, op.cit., note 73, p. 74 
indirectly, to economic benefit, and such proceedings could have led to a criminal conviction if the suspected or accused person had been able to stand trial. ${ }^{110}$

It must be underlined that provisions of the Directive prescribe only minimum conditions, and every state can in its national law prescribe additional or different conditions for in this case extended confiscation, as long as it is in line with the Directive.

Confiscation is not the conviction of the successors, but it can present the restriction of the successors property rights. On the other hand, the need to balance this right with the principle that no one can benefit from criminal offence and the protection of social interest and the public order. ${ }^{111}$ In that regard, in cases of Silickiene $v$ Lithuania ${ }^{112}$ and Raimondo $v$ Italy, ${ }^{113}$ the ECtHR did not find the violation of the right to property (art.1 Protocol I to the Convention) because the restriction of property rights was regulated by law for higher social interests. ${ }^{114}$ This restriction, however must be proportional to the extent necessary to achieve these protection of the objectives. ${ }^{115}$ Also, it should be noted that provisions of the UN Convention against Corruption contain the non-conviction based confiscation in art. $54 . \$ 1 \mathrm{c}$ states that the country "consider taking such measures as may be necessary to allow confiscation of such property without a criminal conviction in cases in which the offender cannot be prosecuted by reason of death, flight or absence or in other appropriate cases. "116

Therefore, according to our opinion, if the person against whom criminal proceedings have been instituted dies, the pecuniary advantage gained by an unlawful act may be confiscated from his/her successors not only when extended confiscation should have taken place but also ordinary one.

110 See Arcifa, G. The new EU Directive on confiscation: A good (even if still prudent) starting point for the Post-Lisbon EU strategy on tracking and confiscating illicit money, May 2014. Università di Catania Online Working Paper 2014/n. 64, p. 3; [http://www.cde.unict.it/sites/default/files/Quaderno\%20 europeo_64_2014.pdf] Accessed 01.03.2019

111 Roksandić Vidlička, S.; Šamota Galjer, M., Političko-gospodarski kriminalitet i prošireno oduzimanje imovinske koristi: Quo vadis, Hrvatska?. Hrvatski ljetopis za kazneno pravo i praksu, Vol. 22, No. 2, 2015, p. 550

112 Judgment Silickiene v Lithuania (2012) EHRR, par. 63 and point 3 of the judgment, [https:// hudoc.echr.coe.int/eng\#\{\%22fulltext $\% 22$ :[\%22Silickiene\%20v\%20Lithuania $\% 22]$, \%22itemid\%22:[\%22001-110261\%22]\}] Accessed 15.03.2019

113 Judgment Raimondo v. Italy, (1994), EHRR, par. 26-33,

[https://hudoc.echr.coe.int/eng\#\{\%22fulltext\%22:[\%22Raimondo\%20v.\%20Italy\%22],\%22itemid\%22:[\%22001-57870\%22]\}] Accessed 15.03.2019

114 Ibid.

115 Ibid.

116 Art. 54. par.1. UNCAC 
If the courts will not follow our standpoint and interpretation, for the reason of clarity, it is our proposal to amend regulation on ordinary confiscation (Art. 77 CC) to stipulate the possibility of non-conviction based confiscation in cases of perpetrator's death.

\subsubsection{Non-conviction based confiscation and statute of limitation}

Interesting question is what happens when the proceeding ends with so called formal decision because the statute of limitations has occurred. In that regard nor CPA nor CC say nothing.

Therefore, our opinion is that CC and CPA should stipulate this situation as well with the same conditions as in case of perpetrator's death for both categories of confiscation (ordinary and extended).

Furthermore, in cases when the person is permanently incapable for the proceeding (in which case the proceeding temporally ends with the decision of the prosecutor in terminating the investigation ${ }^{117}$ or postponement of the hearing $)^{118}$ or is inaccessible to the authorities, the proceeds of crime will be confiscated. This serves as another legitimate reason for acceptance of our proposal. This solution seems to be possible, especially having in mind Art 4 para 2 of the Directive. ${ }^{119}$ As Arcifa also underlines, the Directive in this article uses the term 'at least:'120 the Directive prescribe only minimum conditions, and every state can in its national law prescribe additional or different conditions for in this case extended confiscation, as long as it is in line with the Directive. This openly provides the possibility to introduce such a solution into our legal system.

Furthermore, Ivičević Karas and Roksandić Vidlička referred to the importance of application of confiscation of proceeds of crime when analyzing Croatian Law on Exemption of the statute of limitation for war profiteering and privatization and ownership transformation crimes committed during the period of Homeland war. ${ }^{121}$ The main purpose of this Law, rendered based on the Constitutional

\footnotetext{
117 Art. $223 \mathrm{CPA}$

118 Art. $406 \$ 1 \mathrm{CPA}$

119 Directive 2014/42/EU, op. cit., note 65, par. 13

120 Arcifa, op. cit., note 110 , p. 9

121 Ivičević Karas; Roksandić Vidlička, op. cit., note 77, pp. 243-244. For more see Derenčinović, D., Pravna priroda instituta oduzimanja imovinske koristi i njegovo značenje u prevenciji organiziranog kriminala, Policija i sigurnost, No. 3-4, 1999, pp. 163-164. See related articles of confiscation of pecuniary gain in organized crime cases: Ivičević Karas, E., Oduzimanje imovinske koristi stečene kaznenim djelom u slućajevima organiziranog kriminala - osvrt na problematiku redukcije dokaznog standarda i inverzije tereta dokazivanja, Hrvatska pravna revija, Vol. 4, No. 8, 2004, pp.102-110; Kokić, I., Oduzimanje
} 
amendments in $2010,{ }^{122}$ stipulated in details which economic offences occurred in the process of privatization and ownership transformation occurred during Homeland war and peaceful integration have no statute of limitation (1990-1998).

Persons who have taken advantage of their privileged position or have otherwise acted unlawfully to acquire property, as well as their heirs, cannot expect to keep their gain in a society governed democratically through the rule of law. The underlying public interest in such cases is to restore justice and respect for the rule of law. ${ }^{123}$ Brems goes on that ${ }^{124}$ while the ECtHR generally grants a wide margin of appreciation to national authorities in the area of economic policy, it has broadened this margin in the context of a change in the economic and political regime. ${ }^{125}$ This does not mean that the ECtHR's concrete legal criteria, let alone their application,

are necessarily always in conformity with the ECHR. The Court accepts that the general objective of restitution laws, namely to attenuate the consequences of certain infringements on property rights by Communist regimes, is a legitimate aim and a means of safeguarding the lawfulness of legal transactions and protecting a country's socioeconomic development. However, the Court considers it necessary to ensure that the attenuation of those old injuries does not create disproportionate new wrongs. To that end, it holds that legislation should allow the particular circumstances of each case to be taken into account, so that people who acquired their possessions in good faith are not made to bear a burden of responsibility that is rightfully the burden of the state that once confiscated those possessions. ${ }^{126}$

This reasoning should be applicable in transitional period as well, especially, which included conflict, not only in addressing former totalitarian regimes.

imovinske koristi stečene organiziranim kriminalom u nekim europskim zakonodavstvima, Policija i sigurnost, Vol. 8, n. 3-4, pp. 191-195

122 Constitutional Amendents Official Gazette, No. 89/2010

123 An often-cited case is here Judgment Velikovi et al. v. Bulgaria, (2007) EHRR, par. 162-194, 222, 228, and points 2. and 3. of the judgment, [https://hudoc.echr.coe.int/eng\#\{\%22fulltext\%22:[\%22Velikovi\%22],\%22itemid\%22:[\%22001-79790\%22]\}] Accessed 15.03.2019

124 Brems, E., Transitional Justice in the Case Law of the European Court of Human Rights, International Journal of Transitional Justice, Vol. 5, No, 2, 2011, p. 292

125 See the Judgment Jahn et al. v. Germany (2005) EHRR, par. 1, 2, [https://hudoc.echr.coe.int/eng\#\{\%22fulltext\%22:[\%22Jahn\%22],\%22itemid\%22:[\%22001-69560\%22]\}] Accessed 15.03.2019. See more about the Jahn case in e.g. Lebeck 2006, 359-365

126 Brems, op. cit., note 124, pp. 292-293. See the judgment Pincova and Pinc v. Czech Republic (2002) EHRR,

[https://hudoc.echr.coe.int/eng\#\{\%22fulltext\%22:[\%22Pincova\%20and\%20Pinc\%22],\%22itemid\%22:[\%22001-60726\%22]\}] Accessed 15.03.2019 
Ultimately, in Croatia this resulted in passing constitutional amendments in 2010, which allow for the retroactive prosecution of all transitional economic crimes. The Decision Proposal to Amend the Constitution of Croatia passed for this purpose specified that transformation and privatization do not have the expected economic outcome, i.e. no significant positive impact on the economic development of Croatia ${ }^{127}$

Quite contrary, the implementation of transformation and privatization resulted in the increase of domestic and foreign debt, caused a significant increase in unemployment, disproportionate and fast enrichment of individuals, and unjust impoverishment of many. Also, on the other hand, this implementation caused the fall of wages and pensions in real terms in comparison to costs of living and a number of other consequences. It is just and in the spirit of international law to deny the perpetrators of such grave crimes the possibility to avoid criminal liability by application of the statute of limitations. The basis for the statute of limitations is the guarantee of legal certainty to citizens, but it is certain that this institute should not be the benefit for the perpetrators enabling them to practically legalize the effects of such acts through the statute of limitations. ${ }^{128}$

With regard to the violation of the right to property, the ECtHR concentrates on whether the interferences have clearly fallen within the scope of the legitimate aim of transition and whether the hardships suffered by the applicants have surpassed a certain "threshold of hardship that must be crossed in the condition of transition to find a breach of the right to property." 129

So having in mind todays regulation we don't see why provisions of non-conviction confiscation in CPA shouldn't be amended on cases when criminal proceeding ended with formal decision when statute of limitation has occurred. Also it should be expanded to the cases on which Law on Exemption applies. Taking all of the above, it is our proposal that art. 77 and 78 of the CC should be amended to include the possibility to confiscate the proceeds of crime in cases when the statute of limitation occurs in non-conviction based confiscation.

127 Roksandić Vidlička, S., Prosecuting Serious Economic Crimes as International Crimes- A New Mandate for the ICC?, Duncker \& Humbolt, Berlin, 2017, pp. 115-116

128 Decision Proposal to Amend the Constitution of Croatia 2009, p. 8

129 Varju, M., Transition as a Concept of European Human Rights Law, European Human Rights Law Review, Vol. 14, No. 1, 2009, pp. 175-176. Also in Roksandić Vidlička, S., Tranzicijsko zakonodavstvo i tranzicijska pravda kao metoda ostvarenja Ustavnih vrednota kroz praksu Europskog suda za ljudska prava, (forthcoming, still unpublished paper), 2019 


\subsection{Property rights and confiscation from the third persons in Croatia}

In cases of ordinary confiscation proceeds of crime can be confiscated only from the third persons who were not in good faith. Then again, in cases of extended confiscation proceeds of crime can be confiscated from family members no matter of the ground of the acquisition, and from third persons if they did not acquired in good faith and at a reasonable price. ${ }^{130}$ The extended confiscation makes difference between family members and other persons, while ordinary confiscation does not.

We do not support this distinction. Sometimes a great amount can come from ordinary crimes on which extended confiscation cannot apply. For example, someone steals the car, a Porsche, and makes a gift to his daughter for eighteen birthday who acquires it in good faith. By current solution, it could not be confiscated.

Then again if someone commits the crime on which the extended confiscation applies, for example someone receives the bribe, the car (Porsche) and gives it to his daughter for eighteen birthday, then it can be confiscated. In what way those two situations are different having in mind above mentioned principles that nobody can benefit from the crime, what also protects the principle of justice and guards property rights?

Again, we are of opinion that the regulation when proceeds of crime are transferred to family members should be the same for ordinary and extended confiscation. The rules prescribed for extended confiscation should prevail.

\subsection{Legal nature}

Today, as it was stated, confiscation of proceeds of crime is considered a measure sui generis. ${ }^{131,132}$ Its primary purpose is to restore the state of property as it was prior to the crime (restitutio in integrum), and not to punish the perpetrator. This is also the position of the Croatian Supreme Court. The Supreme Court of the Croatia has taken the stance that confiscation of pecuniary gain has restorative function, ${ }^{133}$ and it is not a sort of punishment. ${ }^{134}$ However, confiscation of proceeds of crime contains repressive elements as well and has to satisfy conditions of proportionality. Today's opinion is that it is not applied ad personam, but in rem. Although declared as a restorative measure, confiscation of pecuniary gain acquired through

\footnotetext{
$130 \quad$ Art $78 \$ 4,5$ CCC

131 Developed under the influence of German legal doctrine

132 see Ivičević Karas; Roksandić Vidlička, op. cit., note 77, pp. 243-244

133 Contributes to the earlier financial status of the victim and the perpetrator

134 Ivičević Karas (a), Komentar..., op. cit. note 99, p. 7
} 
a criminal offence also fulfills the preventive purpose, special and general prevention. As it was mentioned earlier, measure is imposed by a court usually following the judgment the courts should apply it ex officio, regardless of the existence of the proposal of the prosecutor. ${ }^{135}$

Novoselec ${ }^{136}$ and $\operatorname{Kos}^{137}$ considered that previous regulation of this measure deemed this measure more as a punishment, than the measure. ${ }^{138}$ Derenćinović (1999) was also debating about legal nature of this measure and indicated at its importance, and significance in prevention of organized crime (as Kos, 1998; Roksandić Vidlička \& Šamota Galjer, 2015).

\subsubsection{Legal nature of confiscation depending on model of confiscation (conviction based or non-conviction based)}

Conviction based confiscation is actually measure of hybrid nature, primarily ad rem, but it has some elements of sanction, and in that regard is also measure ad presonam. This is in line with ECtHR practice. Issue of the legal nature of the measure of confiscation was the subject of interest of: ECHR, particularly in the case Welch $v$ United Kingdom. ${ }^{139}$ ECHR concluded that, in this case, confiscation should be considered as punishment: "Taking into consideration the combination of punitive elements outlined above, the confiscation order amounted, in the circumstances of the present case, to a penalty. Accordingly, there has been a breach of Article 7 para. 1 (art. 7-1)“. ${ }^{140}$ This case is a landmark case for establishing differences between legal nature of the measures and punishments since the ECHR determine criteria for its discernment. According to ECHR, „... there are several aspects of the

135 Roksandić Vidlićka; Šamota Galjer, op. cit., note 111, p. 544

136 Novoselec, op.cit., note 73, p. 455

137 See Kos, op. cit., note 75, p. 753-759

138 For more see Novoselec, op.cit., note 73, p. 454-459

139 Judgment Welch $v$ United Kingdom, (1995) EHRR, par. 22, [https://hudoc.echr.coe.int/eng\#\{\%22fulltext\%22:[\%22Welch\%22],\%22itemid\%22:[\%22001-57927\%22]\}] Accessed 15.03.2019. "The applicant complained that the confiscation order that was made against him amounted to the imposition of a retrospective criminal penalty, contrary to Article 7 (art. 7) which reads as follows: "1. No one shall be held guilty of any criminal offence on account of any act or omission which did not constitute a criminal offence under national or international law at the time when it was committed. Nor shall a heavier penalty be imposed than the one that was applicable at the time the criminal offence was committed.

This Article (art. 7) shall not prejudice the trial and punishment of any person for any act or omission which, at the time when it was committed, was criminal according to the general principles of law recognized by civilized nations." He emphasized that his complaint was limited to the retrospective application of the confiscation provisions of the 1986 Act and not the provisions themselves ". - par. 22

140 Judgment Welch $v$ United Kingdom, (1995) EHRR, par.35 
making of an order under the 1986 Act which are in keeping with the idea of a penalty as it is commonly understood even though they may also be considered as essential to the preventive scheme inherent in the 1986 Act. ${ }^{\text {"141 }}$ It also concluded "...that all property passing through the offender's hands over a six-year period is the fruit of drug trafficking unless he can prove otherwise (see paragraph 12 above); "I 42 and that it actually has a regime of punishment which can be seen in

1. the fact that the confiscation order is directed to the proceeds involved in drug dealing and is not limited to actual enrichment or profit (see sections 1 and 2 of the 1986 Act in paragraph 12 above);

2. the discretion of the trial judge, in fixing the amount of the order, to take into consideration the degree of culpability of the accused (see paragraph 13 above);

3. and the possibility of imprisonment in default of payment by the offender (see paragraph 14 above)". ${ }^{143}$ Those "are all elements which, when considered together, provide a strong indication of, inter alia, a regime of punishment". ${ }^{144}$

When it is of hybrid nature, ad rem and ad presonam, that it has elements both of the sanction and a measure (see Table 1).

Table 1. Legal nature of confiscation of proceeds of crime

\begin{tabular}{|l|l|l|}
\hline & conviction & non-conviction \\
\hline ad personam & + & - \\
\hline ad rem & + & + \\
\hline & sanction and measure & measure \\
\hline
\end{tabular}

As it can be seen from the Table above, conviction based confiscation of proceeds of crime has hybrid legal nature. Non-conviction based confiscation, is a measure and is applicable ad rem.

Similar stand point has Arcifa when underlying that "the Directive 2014/42/EU aims to harmonize their legislation. At a conceptual level, recovery systems of the proceeds and instrumentalities of crimes can be classified into two broad categories: the non-conviction based confiscation, typical of common-law countries (in this case, confiscation is a measure against property) and the confiscation based on the conviction (here confiscation is a sanction against the person) ". ${ }^{145}$

\footnotetext{
$141 \quad$ Ibid., par. 33

142 Ibid., par. 33

143 Ibid., par. 33

144 Ibid.

145 Arcifa, op. cit., note 110, p. 3
} 
This means it can be imposed on everybody, and proceeds of crime can be confiscated from perpetrator and from third persons to whom is transferred to. Furthermore this reasoning is in line with the main principle that no one can benefit from criminal offence. This also is one of the main arguments for our above mentioned proposals.

\subsection{The question of (financial) efficiency of confiscation of proceeds of crime}

Various studies have indicated that confiscation of pecuniary gain in practice is rare, and inefficient regardless of ex officio obligation of the court to impose this measure. ${ }^{146}$ The research of final judgments in cases of economic crimes, conducted by Novosel, that covered the period between 1998 and 2006, ended with the "disastrous results". ${ }^{147}$

It is important to underline that the success of confiscation could be followed from statistical reports. Discrepancies exist between adjudicated and actually confiscated proceeds of crime. According to data of State Attorney's Office, in 2015 in the first instance judgements, adjudicated amount of confiscated pecuniary gain was 160.381.355,32 HRK (cca 21.102.809,91 mln €). ${ }^{148}$ The largest percentage of the confiscated pecuniary gain 45,7\% (73.292.372,80 HRK; cca 9.643.733,26 $\mathrm{mln} €$ ) was for economic criminal offences. ${ }^{149}$

In 2016 (192.270.016,85 HRK - cca 25.298.686,42 mln €), ${ }^{150}$ from which for economic criminal offences confiscated amount was 131.432.881,00 HRK (cca 17.293.800,13 mln $€),{ }^{151}$ which constitutes $68,36 \%$ of all confiscated proceeds of crime in that year.

In the first instance judgements in 2017, adjudicated amount was 299.633.535,31 HRK (cca 39.425.465,17 mln €), ${ }^{152}$ and frozen amount was 198.295.528,60

146 Ivičević Karas (a), Komentar... op. cit., note 99, p. 3, 13

147 Novosel, D., Financijske istrage i progon počinitelja gospodarskog kriminaliteta, Hrvatski ljetopis za kazneno pravo i praksu, Vol. 14 No. 2, 2007, p.743

148 State Attorney's Office, Report of the State Attorney's Office (DORH) for 2015 (p. 53), Zagreb, 2016; available at: [http://www.dorh.hr/IzvjesceDrzavnogOdvjetnistvaRepublikeHrvatske] Accessed 01.03.2019

149 Ibid., p. 85

150 State Attorney's Office, Report of the State Attorney's Office (DORH) for 2016 (p. 48), Zagreb,2017; available at: [http://www.dorh.hr/IzvjesceDrzavnogOdvjetnistvaRepublikeHrvatskeZa] Accessed 01.03 .2019

151 Ibid., p. 86

152 State Attorney's Office, Report of the State Attorney's Office (DORH) for 2017 (p. 50), Zagreb, 2018; available at: [http://www.dorh.hr/dorh07062018] Accessed 01.03.2019 
HRK (cca 26.091.516,92 mln €). ${ }^{153}$ For economic criminal offences which has the largest percentage in adjudicated amounts, the confiscated (the adjudicated) amount was 193.272.983, 91 HRK (cca 25.430.655, $77 \mathrm{mln} €$ ). ${ }^{154}$ It seems how collected proceeds of crime resulting from economic offenses (especially Art. 246 and 247. CCC) for which the convictions were made, is considerably higher. ${ }^{155}$ However, not so much of adjudicated amounts were really collected, most probably the collected amounts were the frozen ones. Unfortunately, there is no available statistical data on how much of mentioned amounts was actually collected and transferred into the State budget.

One must be aware that perpetrators often do not have the money or other assets which they might be forced to pay if the amounts have not been frozen before. ${ }^{156}$ This is particularly evident in ordinary property crimes (theft, grand larceny, etc.) where the motive for committing a criminal offense is just to acquire resources for everyday life, and even with the attempt of enforced collection, the confiscation of property gain from the perpetrator remains unsuccessful. ${ }^{157}$ But, confiscation of proceeds of crime does not have statute of limitations and the amount could be confiscated in any time, when the perpetrators subsequently acquire property that can be enforced. ${ }^{158}$

\section{CONCLUSION}

As stated in the introduction, confiscation of proceeds of crime is the measure that guards property rights of the primary (rightful) owner, is guardian of the principle of justice, and serves the protection of public interest. This measure is sui generis measure that still awaits to be integrated as an efficient measure in the Croatian legal system. Its legal nature is twofold, depending on model of confiscation conviction based or non-conviction based (see Table 1). In any case, the regulation of this measure must be consistent, regardless whether it is regulated as ordinary or extended measure. Therefore, the authors propose the following amendments,

\footnotetext{
153 Ibid., p. 50

154 Ibid., p. 92

155 The amounts which we are mentioned in State Attorney's Office Report are the amount adjudicated from the first instance courts, so we don't know what percentage of this amounts are adjudicated in final decisions

156 For forzen proceds of crime two regulations the Regulation on the Conditions and Procedures for Managing the temporarily seized Property in Criminal Proceedings Official Gazette, No. 103/2018 and the Rulebook on Procedure with Temporarily Seized Objects, Domestic or Foreign Means of Payment, on Securities and Documentation Official Gazette, No. 39/2017

157 Ibid., p. 50

158 Ibid.
} 
based on the fundamental principle that no one should benefit from committing criminal offence and taking into consideration that the main purpose of this measure is not punishment, but restoring previous state of ownership by protecting property rights of real (primary) owner. Due to that reason, rules on confiscation from third person, or in case of the perpetrator's death, should be the same regardless of the type of implemented confiscation, i.e. ordinary or extended. The same should apply, in our opinion, when the offence become statute barred, i.e. when statute of limitation elapses. Therefore,

1. according to our opinion, if the person against whom criminal proceedings have been instituted dies, the pecuniary advantage gained by an unlawful act may be confiscated from his/her successors not only when extended confiscation should have taken place but also ordinary one. If the courts will not follow our standpoint and interpretation, for the reason of clarity, it is our proposal to amend regulation on ordinary confiscation (Art. $77 \mathrm{CC}$ ) to stipulate the possibility of non-conviction based confiscation in cases of perpetrator's death.

2. Art 77 and 78 of the CC should be amended to include the possibility to confiscate the proceeds of crime in cases when the statute of limitation occurs in non-conviction based confiscation. Also it should be expanded to the cases on which for war profiteering and privatization and ownership transformation crimes committed during the period of Homeland war $^{159}$ applies.

3. the rules prescribed for extended confiscation should prevail (in cases of extended confiscation proceeds of crime can be confiscated from family members no matter of the ground of the acquisition, and from third persons if they did not acquired in good faith and at a reasonable price).

Moreover, in our opinion, the collected proceeds of crime should be invested in social needs of population, e.g. kindergartens, schools, hospitals, for compensating victims of the offences, etc. as well as in investing in crime prevention. ${ }^{160}$

159 Ivičević Karas; Roksandić Vidlička, op. cit., note 77, pp. 243-244. For more see Derenčinović, D., Pravna priroda instituta oduzimanja imovinske koristi i njegovo značenje u prevenciji organiziranog kriminala, Policija i sigurnost, No. 3-4, 1999, pp. 163-164. See related articles of confiscation of pecuniary gain in organized crime cases: Ivičević Karas, E., Oduzimanje imovinske koristi stečene kaznenim djelom u slučajevima organiziranog kriminala - osvrt na problematiku redukcije dokaznog standarda $i$ inverzije tereta dokazivanja, Hrvatska pravna revija. Vol. 4, No. 8, 2004, pp. 102-110; Kokić, I., Oduzimanje imovinske koristi stečene organiziranim kriminalom u nekim europskim zakonodavstvima, Policija i sigurnost, Vol. 8, No. 3-4, pp. 191-195

160 How some other countries have this reguated see Radha, I., Asset Recovery in Four Dimensions: Returning Walth to Victim Countries as a Challenge for Global Governence, in: Ligeti, K.; Simonato, M. (eds.), Chasing Criminal Money - Challenges and Perspectives On Asset Recovery in the EU, Hart, Oxford 
It should be considered to form special fund or special account in State budget on which major part of confiscated assets would be deposited and used for fight against crime. ${ }^{161}$ In this vain, the other problem that one must be aware of, are costs of managing confiscated property, especially costs of managing the real estates. The body in charge of managing and maintaining confiscated property is the Ministry of State Property, ${ }^{162}$ and it is of outmost importance for the mentioned institution to behave like "good entrepreneur and keep or even increase the value of the confiscated property.

One special question which was not elaborated in this paper is why provisions of the extended confiscation (Art 78. CCC) should be applicable to other serious criminal offences such as economic crimes that are not under the scope of USKOK, or other serious crimes like crimes against humanity and human dignity (genocide, crime against humanity, crime of aggression, war crime). But this will stay open as the theme for further research.

\section{REFERENCES}

\section{BOOKS AND ARTICLES}

1. Arai-Takahashi, Y., The Margin of Appreciation Doctrine and the Principle of Proportionality in the Jurisprudence of the ECHR, Antwerp et al., 2002

2. Bačić, F., Kazneno pravo -opći dio, V. izdanje, Zagreb, 1998

3. Bates, E., The Evolution of the European Convention on Human Rights: From its Inception to the Creation of a Permanent Court of Human Rights, Oxford, 2010

4. Boroi, A., Elements of Comparative Law on Extended Confiscation, The $9^{\text {th }}$ Edition of the International Conference European Integration - Realities and Perspectives -EIRP Legal Sciences in the New Millennium, 2014

5. Brems, E., Transitional Justice in the Case Law of the European Court of Human Rights, International Journal of Transitional Justice, Vol. 5, No. 2, 2011, pp. 282-303

6. Carss-Frisk, M., The right to property, A guide to implementation of article 1 of the Protocol No. 1. to the European Convention on Human Rights, Human Rights Handbooks, No. 4. The Council of Europe, 2001

7. Cassella, Stefan D., The American Perspective on Recovering Criminal Proceeeds in Criminal and Non-Conviction Based Proceedings, in: Ligeti, K.; Simonato, M. (eds.), Chasing Crimi-

and Portland, Oregon, 2017, pp. 175-208; Meyer, F., Restitution of Dirty Assets: A Swiss Template for the International Community, in: Ligeti, K.; Simonato, M. (eds.), Chasing Criminal Money - Challenges and Perspectives On Asset Recovery in the EU, Hart, Oxford and Portland, Oregon, 2017, pp. 211229

161 Also proposed in the article Roksandić Vidlićka; Šamota Galjer, op. cit., note 111

162 Art. 563. CPA 
nal Money - Challenges and Perspectives On Asset Recovery in the EU, Hart, Oxford and Portland, Oregon, 2017

8. Christophe Golay, C.; Cismas, I., Legal Opinion: The Right to Property from a Human Rights Perspective 2010

9. Derenčinović, D., Pravna priroda instituta oduzimanja imovinske koristi i njegovo značenje u prevenciji organiziranog kriminala, Policija i sigurnost, n. 3-4, 1999

10. Elizabeta Ivičević, Oduzimanje imovinske koristi stečene kaznenim djelom, Hrvatsko udruženje za kaznene znanosti i praksu, Ministarstvo unutarnjih poslova RH, Zagreb 2004

11. Galiot, M., Oduzimanje imovinske koristi medunarodne pravne stečevine i suzbijanja podmićivanja, Zbornik Pravnog fakulteta Sveučilišta u Rijeci. Vol. 38, No. 1, 2017, pp. $547-572$

12. Grgić, A.; Mataga, Z. Longar, M.; Vilfan, A., The right to property under the Eureopan Convnetion on Human Rights: A guide to the implementation of the European Convnetion on Human Rights and its protocols. Human Rights Handbooks, No.10, Strasborug, 2007

13. Harris, D. J.; O’Boyle, M.; Warbick, C.; Bates, E.; Buckly, C., Law of the European Convention on Human Rights, Oxford University Press, Oxford 2014

14. Horvatić, Ž., Kazneno pravo, Opći dio 1, Sveučilište u Zagrebu, Pravni fakultet, Zagreb 2003

15. Horvatić, Ž., Novoselec, P., Kazneno pravo - opći dio, Zagreb, 2001

16. Horvatić,Ž; Derenčinović, D.; Cvitanović, L., Kazneno pravo opći dio 1., kazneno pravo $i$ kazneni zakon, Pravni fakultet Sveučilišta u Zagrebu, Zagreb, 2016

17. Ivičević Karas, E. (a), Komentar Zakona o postupku oduzimanjima imovinske koristi ostvarene kaznenim djelom i prekršajem, Narodne novine, Zagreb, 2011

18. Ivičević Karas, E. (b), Zakon o postupku oduzimanja imovinske koristi ostvarene kaznenim djelom i prekršajem: neka otvorena pitanja i moguća rješenja, Hrvatski ljetopis za kazneno pravo i praksu (Zagreb), Vol. 18, No. 2, 2011

19. Ivičević Karas, E., Oduzimanje imovinske koristi stečene kaznenim djelom u slućajevima organiziranog kriminala - osvrt na problematiku redukcije dokaznog standarda i inverzije tereta dokazivanja, Hrvatska pravna revija. 4,8, 2004

20. Ivičević Karas, E., Zakon o postupku oduzimanja imovinske koristi ostvarene kaznenim djelom i prekršajem: neka otvorena pitanja i moguća rješenja, Hrvatski ljetopis za kazneno pravo i praksu, Vol. 18, No. 2, 2011, pp. 557-578

21. Ivičević Karas, E.; Roksandić Vidlička, S., The Relevence of Asset Recovery Policies in Transitional Societies: The Croatian Perspecitve in Chasing Criminal Money in: in: Ligeti, K.; Simonato, M. (eds.), Challenges and Perspectives On Asset Recovery in the EU, Hart, Oxford and Portland, Oregon, 2017.

22. Kaleb, Z., Novo uredenje instituta oduzimanja imovinske koristi prema noveli Kaznenog zakona sosvrtom na dosadašnju sudsku praksu - usporedba sodlukom o imovinskopravnom zahtjevu, Hrvatski ljetopis za kazneno pravo i praksu (Zagreb), Vol. 10, No. 2, 2003, pp. 449-478

23. Kokić, I., Oduzimanje imovinske koristi stečene organiziranim kriminalom u nekim europskim zakonodavstvima, Policija i sigurnost, Vol. 8, n. 3-4.

24. Kos, D., Problematika oduzimanja imovinske koristi, Hrvatski ljetopisa za kazneno pravo i praksu, Vol. 5, No. 2, 1998 
25. Kurtović, A., Zakonska rješenja u svijetlu primjene mjera upozorenja, sigurnosnih mjera i oduzimanja imovinske koristi, Hrvatski ljetopis za kazneno pravo i praksu, Vol. 7, No. 2, 2000

26. Meyer, F., Restitution of Dirty Assets: A Swiss Template for the International Community, in: Ligeti, K.; Simonato, M. (eds.), Chasing Criminal Money - Challenges and Perspectives On Asset Recovery in the EU, Hart, Oxford and Portland, Oregon, 2017, pp. 211-229

27. Novosel, D., Financijske istrage i progon počinitelja gospodarskog kriminaliteta, Hrvatski ljetopis za kazneno pravo i praksu, Vol. 14 No. 2, 2007, pp. 739-783

28. Novoselec, P., Opći dio kaznenog prava, Osijek, 2016

29. Radha, I., Asset Recovery in Four Dimensions: Returning Walth to Victim Countries as a Challenge for Global Governence, in: Ligeti, K.; Simonato, M. (eds.), Chasing Criminal Money - Challenges and Perspectives On Asset Recovery in the EU, Hart, Oxford and Portland, Oregon, 2017, pp. 175-208

30. Roksandić Vidlička, S., Prosecuting Serious Econimic Crimes as International Crimes, A New Mandate for the ICC?, Duncker\&Humblot, Berlin, 2017

31. Roksandić Vidlička, S., Tranzicijsko zakonodavstvo i tranzicijska pravda kao metoda ostvarenja Ustavnih vrednota kroz praksu Europskog suda za ljudska prava, (forthcoming, still unpublished paper), 2019

32. Roksandić Vidlička, S.; Šamota Galjer, M., Političko-gospodarski kriminalitet i prošireno oduzimanje imovinske koristi: Quo vadis, Hrvatska?. Hrvatski ljetopis za kazneno pravo i praksu, Vol. 22, No. 2,2015

33. Varju, M. Transition as a Concept of European Human Rights Law, European Human Rights Law Review, Vol. 14, No. 1, 2009, pp. 170-189

34. Vettori, B.; Zanella, M., Going beyond the confi scation of proceeds from organised crime activities: Stripping away ill-gotten gains from corruption in the enlarged Europe, Apeldoorn, NL, 2011

\section{LIST OF NATIONAL REGULATIONS, ACTS AND COURT DECISIONS}

1. Constitution of Republic of Croatia, Official Gazette, No. 56/1990, 135/1997, 08/1998, 113/2000, 124/2000, 28/2001, 41/2001, 55/2001, 76/2010, 85/2010, 05/2014

2. Criminal Code, Official Gazette, No 125/2011, 144/2012, 56/2015, 61/2015, 101/2017, $118 / 2018$

3. Protocol to the Convention for the Protection of Human Rights and Fundamental Freedoms, Narodne novine, Međunarodni ugovori, br. 6/1999

4. Criminal Procedural Act, Official Gazette, No. 152/2008, 76/2009, 80/2011, 91/2012, $143 / 2012,56 / 2013,145 / 2013,521 / 2014,70 / 2017$

5. The Law on the Liability of Legal Persons for Criminal Offenses, Official Gazette, No. $151 / 2003,110 / 2007,45 / 2011,143 / 2012$

6. The Law on Mutual Legal Assistance in Criminal Matters, Official Gazette, No. 178/2004.

7. Act on Proceedings of Confiscation of Pecuniary Gain Acquired Through a Criminal Offence and Misdemeanours Official Gazette, No. 145/2010, 70/2017 
8. The Law on Office for Prevention Corruption and Organized Crime, Official Gazette, No 76/2009, 116/2010, 145/2010, 57/2011, 136/2012, 148/2013, 70/2017

9. State Attorney's Office, Report of the State Attorney's Office (DORH) for 2015 (p. 53), Zagreb, 2016; available at: [http://www.dorh.hr/IzvjesceDrzavnogOdvjetnistvaRepublikeHrvatske] Accessed 01.03.2019

10. State Attorney's Office, Report of the State Attorney's Office (DORH) for 2016 (p. 48), Zagreb,2017; available at: [http://www.dorh.hr/IzvjesceDrzavnogOdvjetnistvaRepublikeHrvatskeZa] Accessed 01.03.2019

11. State Attorney's Office, Report of the State Attorney's Office (DORH) for 2017 (p. 50), Zagreb, 2018, available at: [http://www.dorh.hr/dorh07062018] Accessed 01.03.2019

12. The Regulation on the Conditions and Procedures for Managing the temporarily seized Property in Criminal Proceedings Official Gazette, No. 103/2018

13. The Rulebook on Procedure with Temporarily Seized Objects, Domestic or Foreign Means of Payment, on Securities and Documentation Official Gazette, No. 39/2017

14. Act on Ownership and Other Real Rights, Official Gazette, No 91/1996, 68/1998, 137/1999, 22/2000, 73/2000, 129/2000, 114/2001, 79/2006, 141/2006, 146/2008, $38 / 2009,153 / 2009,143 / 2012,152 / 2014$

15. Civil Obligations Act, Official Gazette, No. 35/2005, 41/2008, 125/2011, 78/2015, $29 / 2018$

\section{LIST OF REGULATIONS}

1. Convention on Laundering, Search, Seizure and Confiscation of the Proceeds from Crime. ETS No. 141 i Narodne novine, Međunarodni ugovori 14/1997

2. Council Framework Decision 2001/500/JHA of 26 June 2001 on Money Laundering, the Identification, Tracing, Freezing, Seizing and Confiscation of Instrumentalities and the Proceeds of Crime [2001] OJ L182/1

3. Council Framework Decision 2003/577/JHA of 22 July 2003 on the execution in the European Union of orders freezing property or evidence, [2003] OJ L-196/45

4. Council Framework Decision 2005/212/JHA of 24 February 2005 on Confiscation of Crime-Related Proceeds, Instrumentalities and Property [2005] L 68/49

5. Council Framework Decision 2008/841/JHA of 24 October 2008 on the fight against organised crime [2008] L 300/42

6. Council of Europe Convention on Laundering, Search, Seizure and Confiscation of the Proceeds from Crime, 1990., [https:/www.coe.int/en/web/conventions/full-list/-/conventions/treaty/141] Accessed 27.03.2019

7. Council of Europe Convention on the Prevention of Terrorism, 2005., [https://www.coe. int/en/web/conventions/full-list/-/conventions/treaty/196] Accessed 27.03.2019

8. Council of Europe Convention on Laundering, Search, Seizure and Confiscation of the Proceeds from Crime and on the Financing of Terrorism, 2005., [https://www.coe.int/en/ web/conventions/full-list/-/conventions/treaty/198] Accessed 27.03.2019

9. Criminal Law Convention on Corruption, 1999, [https://www.coe.int/en/web/conventions/full-list/-/conventions/treaty/173], Accessed 27.03.2019 
10. Directive 2014/42/EU of the European Parliament and of the Council of 3 April 2014 on the freezing and confiscation of instrumentalities and pecuniary gain in the European Union [2014] L 127/39

11. FATF, International Standards on Combating Money Laundering and the Financing of Terrorism \& Proliferation: The FATF Recommendations (October 2002, updated June 2017), [http://www.fatf-gafi.org/media/fatf/documents/recommendations/pdfs/FATF\%20Recommendations\%202012.pdf] Accessed 27.03.2019

12. International Convention for the Suppression of the Financing of Terrorism, 1999, [https:// www.unodc.org/documents/treaties/Special/1999\%20International\%20Convention $\% 20$ for $\% 20$ the $\% 20$ Suppression $\% 20$ of $\% 20$ the $\% 20$ Financing\%20of $\% 20$ Terrorism.pdf] Accessed 27.03.2019

13. Protocol to the Convention for the Protection of Human Rights and Fundamental Freedoms [https://www.echr.coe.int/Documents/Convention_ENG.pdf] Accessed 20.03.2019

14. United Nations Convention against Corruption, 2003, [https://www.unodc.org/documents/brussels/UN_Convention_Against_Corruption.pdf] Accessed 27.03.2019

15. United Nations Convention against Illicit Traffic in Narcotic Drugs and Psychotropic Substances, 1988, [https://www.unodc.org/pdf/convention_1988_en.pdf] Accessed 27.03.2019

16. United Nations Convention against Transnational Organized Crime and the Protocols Thereto, 2000, [https://www.unodc.org/documents/middleeastandnorthafrica/organised-crime/UNITED_NATIONS_CONVENTION_AGAINST_TRANSNATIONAL_ORGANIZED_CRIME_AND_THE_PROTOCOLS_THERETO.pdf] Accessed 27.03.2019

\section{ECHR}

1. Denisova and Moiseyeva v. Russia, (2010) \$ 58, EHRR, [https://hudoc.echr.coe.int/ eng\#\{\%22fulltext $\% 22$ :[\%22Denisova $\% 20$ and $\% 20$ Moiseyeva $\% 22], \% 22$ documentc ollectionid2\%22:[\%22GRANDCHAMBER\%22,\%22CHAMBER\%22],\%22item id\%22:[\%22001-98018\%22]\}] Accessed 03.03.2019

2. Džinić v Croatia (2016) EHRR, [https://hudoc.echr.coe.int/eng\#\{\%22fulltext\%22:[\%22D\% C5\%BEini\%C4\%87\%22],\%22itemid\%22:[\%22001-162868\%22]\}] Accessed 27.03.2019

3. Geerings $v$ Netherlands (2007), EHRR, par. 36, [https://hudoc.echr.coe.int/eng\#\{\%22fulltex t\%22:[\%2230810/03\%22],\%22itemid\%22:[\%22001-79657\%22]\}] Accessed 10.03.2019

4. Grayson \& Barnham v UK (2008) EHRR, par. 37-41, 45-50, [https://hudoc.echr. coe.int/eng\#\{\%22fulltext \%22:[\%22Grayson\%20\&\%20Barnham\%22],\%22item id\%22:[\%22001-88541\%22]\}] Accessed 10.03.2019

5. Holy Monasteries v. Greece (1997) EHRR 50, [https://hudoc.echr.coe.int/ eng\#\{\%22fulltext\%22:[\%22Holy\%20Monasteries\%20v.\%20Greece\%22],\%22item id\%22:[\%22001-58180\%22]\}] Accessed 26.03.2019

6. Jahn et al. v. Germany (2005) EHRR, par. 1, 2, [https://hudoc.echr.coe.int/eng\#\{\%22fulltext \%22:[\%22Jahn\%22],\%22itemid\%22:[\%22001-69560\%22]\}] Accessed 15.03.2019 
7. Marckx v. Belgium (1979), EHRR, par. 63., [https://hudoc.echr.coe.int/ eng\#\{\%22fulltext \%22: [\%22 Marckx\%20v.\%20 Belgium \%22], \%22 item id\%22:[\%22001-57534\%22]\}] Accessed 26.03.2019

8. Phillips $v U K(2001)$ EHRR, par. 33, [https://hudoc.echr.coe.int/eng\#\{\%22fulltext $\% 22:[\% 22$ Phillips\%22],\%22itemid\%22:[\%22001-59558\%22]\}] Accessed 10.03.2019

9. Raimondo v. Italy, (1994), EHRR, par. 26-33, [https://hudoc.echr.coe.int/ eng\#\{\%22fulltext\%22:[\%22 Raimondo\%20v.\%20 Italy\%22], \%22 item id\%22:[\%22001-57870\%22]\}] Accessed 15.03.2019

10. Salabiaku v France (1988) EHRR, par. 26, 27, [https://hudoc.echr.coe.int/eng\#\{\%22fullte xt\%22:[\%22Salabiaku\%20v\%20France\%22],\%22itemid\%22:[\%22001-57570\%22]\}] Accessed 10.03.2019

11. Saliba et al. v. Malta (2013) EHRR, par. 37., [https://hudoc.echr.coe.int/

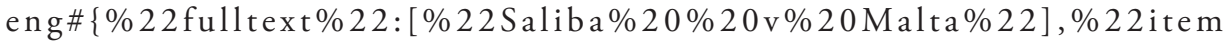
id\%22:[\%22001-116073\%22]\}] Accessed 20.03.2019

12. Silickiene $v$ Lithuania (2012) EHRR, par. 63 and point 3 of the judgment, [https://hudoc. echr.coe.int/eng\#\{\%22fulltext\%22:[\%22Silickiene\%20v\%20Lithuania\%22],\%22item id\%22:[\%22001-110261\%22]\}] Accessed 15.03.2019

13. Sporrong and Lönnroth v. Sweden (1984) EHRR 50, [https://hudoc.echr.coe.int/ eng\#\{\%22fulltext \%22:[\%22Sporrong\%20and\%20L\%C3\%B6nnroth\%20v.\%20Sweden $\% 2$ 2],\%22itemid\%22:[\%22001-57579\%22]\}] Accessed 26.03.2019

14. Tre Traktörer Aktiebolag v. Sweden (1989), EHRR, par. 46., [https://hudoc.echr.coe.int/ eng\#\{\%22fulltext\%22:[\%22Tre\%20Trakt\%C3\%B6rer\%20Aktiebolag\%22],\%22item id\%22:[\%22001-57586\%22]\}] Accessed 27.03.2019

15. Valkov et al. v. Bulgaria (2011) EHRR, par. 79, 80, 84-91., [https://hudoc.echr.coe.int/en g\#\{\%22fulltext\%22:[\%22Valkov\%22],\%22itemid\%22:[\%22001-107157\%22]\}] Accessed 20.03.2019

16. Veits v. Estonia (2015) par. 71 EHRR; [https://hudoc.echr.coe.int/ eng\#\{\%22fulltext\%22:[\%22 Veits\%20v\%20 Estonia\%22], \%22 item id\%22:[\%22001-150303\%22]\}] Accessed 03.03.2019

17. Velikovi et al. v. Bulgaria, (2007) EHRR, par. 162-194, 222, 228; [https://hudoc.echr.coe. int/eng\#\{\%22fulltext\%22:[\%22Velikovi\%22],\%22itemid\%22:[\%22001-79790\%22]\}] Accessed 15.03.2019

18. Welch $v$ United Kingdom, (1995) EHRR, par. 22, [https://hudoc.echr.coe.int/eng\#\{\%22fulltex t\%22:[\%22Welch\%22],\%22itemid\%22:[\%22001-57927\%22]\}] Accessed 15.03.2019

\section{COURT OF JUSTICE OF THE EUROPEAN UNION}

1. Case 44/79 Liselotte Hauer v. Land Rheinland-Pfalz. [1979] ECR, Reference for a preliminary ruling: Verwaltungsgericht Neustadt an der Weinstraße, Germany. Prohibition of new planting of vines, [https://eur-lex.europa.eu/legal-content/EN/TXT/PDF/?uri=CELEX:61 979CJ0044\&from=EN] Accessed 20.03.2019

\section{WEBSITE REFERENCES}


1. Equality and Human Rights Commission, The First Protocol The First Protocol to the European Convention on Human Rights contains three further fundamental rights in $\mathrm{Hu}-$ man Rights Review 2012 How fair is Britain? An assessment of how well public authorities protect human rights, p. 424, [https:/www.equalityhumanrights.com/sites/default/files/ human-rights-review-2012.pdf] Accessed 26.03.2019

2. Human rights files, No. 11 rev. The European Convention on Human Rights and Property Rights by Laurent Sermet Professeur, University of La Réunion, Conceil d'Europe 1999, p. 8, [https://www.echr.coe.int/LibraryDocs/DG2/HRFILES/DG2-EN-HRFILES-11(1998). pdf] Accessed 26.03.2019

3. The right to property - Introduction, [http://echr-online.info/right-to-property-article1-of-protocol-1-to-the-echr/introduction/] Accessed 20.03.2019

4. UN Human Rights Office of the High Commissioner Publication on Transitional Justice and Economic, Social and Cultural Rights 2014, pp. 28-29, [https://www.ohchr.org/Documents/Publications/HR-PUB-13-05.pdf] Accessed 26.03.2019

\section{WEBSITE REFERENCES (BOOKS AND ARTICLES)}

1. Arcifa, G., The new EU Directive on confiscation: A good (even if still prudent) starting point for the Post-Lisbon EU strategy on tracking and confiscating illicit money, May 2014. Università di Catania - Online Working Paper 2014/n. 64., p. 3, [http://www.cde.unict.it/sites/default/ files/Quaderno\%20uropeo_64_2014.pdf] Accessed 01.03.2019

2. Moiseienko, A., The ownership of confiscated proceeds of corruption under the un convention against corruption, International and Comparative Law Quarterly Q, Vol. 67, July 2018, (pp 669-694), [https://www.cambridge.org/core/services/aop-cambridge-core/content/view/ 2C0108B5CB28B75294D9C10257F17653/S002058931800012Xa.pdf/ownership_of_ confiscated_proceeds_of_corruption_under_the_un_convention_against_corruption.pdf] Accessed 27.03.2019

3. Petranović M., Oduzimanje imovinske koristi ostvarene kaznenim djelom; [www.vsrh.hr/CustomPages/.../MPetranovic-Oduzimanje_imovinske_koristi_ostv.doc] Accessed 01.03.2019

4. Vučko, M.; Šamota Galjer, M., Imovinski izvidi i privremene mjere osiguranja radi primjene instituta oduzimanja imovinske koristi ostvarene kaznenim djelom i prekrš́ajem- Priručnik za polaznike/ice, Pravosdna Akademija, Zagreb; 2016, [http://pak.hr/cke/obrazovni\%20materijali/Imovinski\%20izvidi\%20i\%20privremene\%20mjere\%20osiguranja.pdf] Accessed 12.03.2019 